\title{
ANALISIS KEMAMPUAN MENULIS KARYA ILMIAH DALAM MATA KULIAH BAHASA INDONESIA (STUDI PADA MAHASISWA PGSD ANGKATAN 2016)
}

\author{
Rian Damariswara dan Frans Aditia Wiguna \\ Universitas Nusantara PGRI Kediri \\ Riandamar08@unpkediri.ac.id
}

\begin{abstract}
ABSTRAK
Mahasiswa PGSD angkatan 2016 yang menempuh perkuliahan Bahasa Indonesia perlu dianalisis kemampuannya dalam menulis karya ilmiah. Mahasiswa PGSD merupakan calon guru SD yang mengajarkan tata tulis secara ilmiah kepada siswa di tingkat dasar, jadi perlu adanya penguatan dalam kemampuan menulis karya ilmiah. Pendekatan penelitian adalah kualitatif deskriptif. Sumber data adalah mahasiswa PGSD UN PGRI Kediri angkatan 2016. Data adalah hasil pengerjaan mahasiswa yakni penulisan artikel ilmiah. Teknik pengumpulan data dalam penelitian adalah tes. Teknik analisis data yang digunakan adalah model Miles and Huberman. Langkah-langkahnya yaitu, reduksi data, penyajian data, dan penarikan kesimpulan. Teknik keabsahan data yang digunakan adalah trianggulasi. Hasil penelitian pertama, kemampuan menulis sistematika artikel ilmiah. Sebanyak 17 kelompok atau $85 \%$ dikategorikan baik atau dapat menulis sistematika artikel ilmiah. Sisanya, 3 kelompok atau 15\% dikategorikan perlu bimbingan. Kedua, kemampuan mahasiswa dalam menulis isi artikel ilmiah. Isi pada penulisan judul, nama penulis, abstrak, metode penelitian, dan daftar pustaka mahasiswa dikategorikan baik karena lebih dari $75 \%$ sudah bisa menulis. Sisanya, pada penulisan pendahuluan, hasil penelitian, pembahasan, kesimpulan dan saran, mahasiswa dikategorikan perlu bimbingan dikarenakan hanya $25 \%$ yang dapat menulis dengan baik. Ketiga, kemampuan penggunaan ejaan bahasa Indonesia. Ditemukan beberapa kesalahan, yang perlu diperhatikan yakni kesalahan huruf kapital, huruf miring, tanda titik, tanda koma, dan kata baku. Kesalahan tersebut, dikarenakan mahasiswa kurang membaca karya ilmiah, sehingga pengetahuan penggunaan ejaan bahasa Indonesia masih relatif kurang.
\end{abstract}

Kata Kunci: karya ilmiah, mata kuliah Bahasa Indonesia

\section{ABSTRACT}

The 2016 PGSD students who take Indonesian language courses need to be analyzed for their ability to write scientific papers. PGSD students are elementary school teacher candidates who teach scientific writing to students at the elementary level, so there is a need to strengthen the ability to write scientific papers. The research approach is descriptive qualitative. The data source is PGSD Kediri UN students in class 2016. Data is the result of student work, namely scientific article writing. The technique of collecting data in research is a test. The data analysis technique used is the Miles and Huberman model. The steps are, data reduction, data presentation, and conclusion. The data validity technique used is triangulation. The results of the first study, the ability to write systematic scientific articles. 17 groups or 
$85 \%$ are categorized as good or can write systematic scientific articles. The remaining 3 groups or $15 \%$ are categorized as needing guidance. Second, the ability of students to write the contents of scientific articles. The contents of the title, author's name, abstract, research method, and bibliography of students are categorized as good because more than $75 \%$ can already write. The rest, in preliminary writing, the results of research, discussions, conclusions and suggestions, students are categorized as needing guidance because only $25 \%$ can write well. Third, the ability to use Indonesian spelling. Some errors were found, which need to be considered namely capital letters, italics, periods, commas, and standard words.This error is caused by students not reading scientific work, so the knowledge of using Indonesian spelling is still relatively lacking.

Keywords: scientific paper, Indonesian language courses

\section{PENDAHULUAN}

Mata kuliah Bahasa Indonesia merupakan salah satu dari keempat mata kuliah wajib di perguruan tinggi. Undang-Undang Nomor 12 Tahun 2012 tentang Pendidikan Tinggi dalam pasal 35 ayat 3 menyatakan bahwa kurikulum pendidikan tinggi wajib memuat mata kuliah Agama, Pancasila, Kewarganegaraan dan Bahasa Indonesia untuk program sarjana dan diploma. Salah satu program sarjana yang melaksanakan mata kuliah Bahasa Indonesia adalah S1 PGSD UN PGRI Kediri. Prodi tersebut, dijadikan subjek penelitian khususnya bagi mahasiswa PGSD angkatan 2016 yang menempuh perkuliahan Bahasa Indonesia di semester lima. Alasan pemilihan mahassiwa PGSD karena mahasiswa PGSD merupakan calon guru SD yang mengajarkan tata tulis secara ilmiah kepada siswa di tingkat dasar. Dibutuhkan kemampuan menulis ilmiah yang baik untuk diajarkan kepada siswa SD. Jika calon guru SD belum menguasai kemampuan menulis ilmiah yang baik, maka pondasi pembelajaran menulis ilmiah di SD menjadi tidak kuat. Akibatnya, siswa pada tingkatan selanjutnya akan mengalami kesulitan atau banyak hambatan. Selain itu, mahasiswa PGSD berkewajiban menyusun karya tulis ilmiah sebagai tugas akhir memperoleh gelar sarjana pendidikan. Kedua alasan tersebut, sesuai dengan tujuan perkuliahan Bahasa Indonesia.

Tujuan mata kuliah Bahasa Indonesia supaya mahasiswa terampil menggunakan bahasa Indonesia terutama dalam kegiatan ilmiah. Salah satu kegiatan ilmiah adalah menulis karya ilmiah. Dalam penelitian ini, dibatasi pada penulisan artikel ilmiah. Artikel ilmiah adalah karya tulis yang dirancang untuk dimuat di jurnal 
atau buku kumpulan artikel, ditulis dengan tata cara ilmiah disesuaikan dengan konvensi ilmiah yang berlaku (Suyitno, 2011:91). Berdasarkan pendapat tersebut, artikel ilmiah berbeda karya tulis ilmiah yang lain. Perbedaannya terdapat dalam penuangan hasil karya, yakni artikel ilmiah dimuat di jurnal. Perbedaan yang lain, terdapat dalam sistematika penulisan. Sistematika penulisan artikel ilmiah menurut Suyitno (2011:93) meliputi: 1) judul artikel, 2) nama penulis, 3) abstrak dan kata kunci, 4) pendahuluan, 5) metode penelitian, 6) hasil penelitian, 7) pembahasan, 8) kesimpulan dan saran, dan 9) daftar pustaka. Sistematika tersebut, seperti sistematika penyusunan skripsi atau tugas akhir tetapi dalam artikel ilmiah dibatasi oleh jumlah halaman. Ismawati (2012:68) menambahkan bahwa sistematika artikel ilmiah mengikuti kaidah, pola, dan teknik penulisan ditetapkan oleh wadah atau institusi pencetak jurnal. Artinya, sistematika yang berjumlah sembilan bukan merupakan sistrmatika yang baku, tetapi bisa menyesuaikan dengan institusi pembuat jurnal. Selain dua perbedaan antara artikel ilmiah dengan karya ilmiah yang lain tersebut, artikel ilmiah memiliki kesamaan dangan karya ilmiah yang lain dalam hal penggunaan bahasa. Bahasa yang digunakan dalam artikel ilmiah diuraikan oleh Brotowidjoyo (2002:9) yakni bahasa yang konkret, gaya bahasanya formal, katakatanya teknis, dan didukung dengan fakta umum yang dapat dibuktikan kebenarannya.

Berdasarkan uraian tersebut, penelitian bertujuan menganalisis 1) kemampuan mahasiswa menulis sistematika artikel ilmiah, 2) kemampuan mahasiswa dalam menulis isi artikel ilmiah sesuai sistematikanya, dan 3) kemampuan penggunaan ejaan bahasa Indonesia dalam penulisan artikel ilmiah.

\section{METODE PENELITIAN}

Pendekatan penelitian yang digunakan adalah kualitatif dengan jenis penelitian deskriptif. Artinya, penelitian yang menggambarkan data dalam bentuk susunan kata-kata. Sumber data adalah mahasiswa PGSD UN PGRI Kediri angkatan 2016. Data adalah hasil pengerjaan mahasiswa yakni penulisan artikel ilmiah. Teknik pengumpulan data dalam penelitian adalah tes. Tes menurut Arikunto (2010:193) adalah serentetan pertanyaan atau latihan serta alat yang digunakan untuk mengukur keterampilan, pengetahuan, intelegensi, kemampuan, atau bakat yang dimiliki oleh 
individu atau kelompok. Tes yang digunakan adalah pembuatan artikel ilmiah oleh mahasiswa secara berkelompok. Mahasiswa dengan jumlah 60 dibentuk menjadi 20 kelompok. Masing-masing kelompok beranggotakan 3 mahasiswa. Pembuatan artikel ilmiah dilakukan pada akhir perkuliahan setelah mahasiswa mendapat bekal penulis karya ilmiah dan ejaan bahasa Indonesia. Mahasiswa diberi kebebasan dalam membuat artikel ilmiah.

Teknik analisis data yang digunakan adalah model Miles and Huberman. Langkah-langkahnya yaitu, reduksi data, penyajian data, dan penarikan kesimpulan. Reduksi data, peneliti memilah data yang sesuai dengan tujuan penelitian yakni susunan sistematika, isi dalam sistematika, dan penggunaan ejaan. Hal-hal di luar tujuan penelitian akan diabaikan. Setelah dipilah sesuai tujuan penelitian, dilakukan penyaian data yakni menggunakan persentase dan analisis mendalam mengenai data. Persentase dilakukan untuk mempermudah membaca data dan dapat dijadikan tolak ukur analsiis data. Analisis mendalam berisi uraian kata-kata yang memperjelas hasil persentase.

Teknik keabsahan data yang digunakan adalah trianggulasi. Trianggulasi menurut Moleong (2005:330) yakni teknik pemeriksaan keabsahan data yang memanfaatkan suatu yang lain di luar data itu untuk keperluan pengecekan atau sebagai pembanding terhadap data tersebut. Trianggulasi yang dilakukan yakni kepada mahasiswa selaku sumber data melalui wawancara dan dosen sejawat selaku ahli bahasa Indonesia.

\section{PEMBAHASAN}

\section{Hasil Penelitian}

Mahasiswa PGSD UN PGRI Kediri berjumlah 60 mahasiswa dibentuk menjadi 20 kelompok. Masing-masing kelompok beranggotakan tiga mahasiswa. Setiap kelompok diberi tes untuk membuat artikel ilmiah berdasarkan perkuliahan. Sebanyak 17 kelompok atau 85\% dapat menyusun sistematika artikel ilmiah. Sisanya, sebanyak 3 kelompok atau $15 \%$ masih perlu bimbingan dalam penyususn sistematika artikel ilmiah. 
Tabel 1 Kemampuan Menulis Sistematika Artikel Ilmiah

\begin{tabular}{|c|c|c|}
\hline $\begin{array}{c}\text { Jumlah } \\
\text { Kelompok }\end{array}$ & Persentase & Keterangan \\
\hline 17 & $85 \%$ & Baik \\
\hline 3 & $15 \%$ & Perlu bimbingan \\
\hline 20 & $100 \%$ & - \\
\hline
\end{tabular}

Setelah dianalisis sistematikanya, peneliti menganalisis isi yang ditulis pada setiap bagian artikel ilmiah. Kemampuan menulis isi artikel ilmiah dipaparkan sebagai berikut. 1) Kemampuan menulis judul dan nama penulis sebanyak 20 kelompok atau $100 \%$ dapat menulis judul dengan baik. 2) Kemampuan menulis abstrak dan kata kunci sebanyak 18 kelompok atau 90\% dapat menulis dengan baik, sisanya 2 kelompok atau 10\% masih butuh bimbingan. 3) Kemampuan menulis pendahuluan sebanyak 12 kelompok atau $60 \%$ dapat menulis dengan baik, sisanya 8 kelompok atau $40 \%$ masih butuh bimbingan. 4) Kemampuan menulis metode penelitian sebanyak 17 kelompok atau 85\% dapat menulis dengan baik, sisanya 3 kelompok atau 15\% masih butuh bimbingan. 5) Kemampuan penulisan hasil penelitian sebanyak 9 kelompok atau $45 \%$ dapat menulis dengan baik, sisanya 11 kelompok atau 55\% masih butuh bimbingan. 6) Kemampuan menulis pembahasan sebanyak 3 kelompok atau 15\% dapat menulis dengan baik, sisanya 17 kelompok atau $85 \%$ masih butuh bimbingan. 7) Kemampuan menulis kesimpulan dan saran sebanyak 10 kelompok atau 50\% dapat menulis dengan baik, sisanya 10 kelompok atau 50\% masih butuh bimbingan. 8) Kemampuan menulis daftar pustaka sebanyak 19 kelompok atau 95\% dapat menulis dengan baik, sisanya 1 kelompok atau 5\% masih butuh bimbingan.

Tabel 2 Kemampuan Menulis Isi Artikel Ilmiah Berdasarkan Sistematikanya

\begin{tabular}{|l|c|c|c|}
\hline \multicolumn{1}{|c|}{ Sistematika } & $\begin{array}{c}\text { Jumlah } \\
\text { Kelompok }\end{array}$ & Persentase & Keterangan \\
\hline judul dan nama penulis & 20 & $100 \%$ & Baik \\
\hline abstrak dan kata kunci & 15 & $75 \%$ & Baik \\
\cline { 2 - 4 } & 5 & $25 \%$ & Perlu Bimbingan \\
\hline Pendahuluan & 12 & $60 \%$ & Baik \\
\cline { 2 - 4 } & 8 & $40 \%$ & Perlu Bimbingan \\
\hline metode penelitian & 17 & $85 \%$ & Baik \\
\cline { 2 - 4 } & 3 & $15 \%$ & Perlu Bimbingan \\
\hline
\end{tabular}




\begin{tabular}{|l|c|c|c|}
\hline \multicolumn{1}{|c|}{ Sistematika } & $\begin{array}{c}\text { Jumlah } \\
\text { Kelompok }\end{array}$ & Persentase & Keterangan \\
\hline hasil penelitian & 9 & $45 \%$ & Baik \\
\cline { 2 - 4 } & 11 & $55 \%$ & Perlu Bimbingan \\
\hline Pembahasan & 3 & $15 \%$ & Baik \\
\cline { 2 - 4 } & 17 & $85 \%$ & Perlu Bimbingan \\
\hline kesimpulan dan saran & 10 & $50 \%$ & Baik \\
\cline { 2 - 4 } & 10 & $50 \%$ & Perlu Bimbingan \\
\hline daftar pustaka & 19 & $95 \%$ & Baik \\
\hline & 1 & $5 \%$ & Perlu Bimbingan \\
\hline
\end{tabular}

Analisis isi dari sistematika, dipertajam dengan analisis penggunaan ejaan bahasa Indonesia. Kemampuan penggunaan ejaan bahasa Indonesia dalam penelitian dibatasi pada 1) penulisan huruf meliputi, huruf kapital dan huruf miring; 2) penulisan tanda baca meliputi, tanda titik dan koma; dan 3) penulisan kata baku. Dalam penulisan huruf, yakni a) huruf kapital ditemukan kesalahan sebanyak 50 huruf dan b) huruf miring ditemukan kesalahan sebanyak 5 huruf. Dalam penulisan tanda baca, yakni a) tanda titik ditemukan kesalahan sebanyak 45 dan b) tanda koma ditemukan sebanyak 20. Dalam penulisan kata baku, ditemukan sebanyak 30 kata tidak baku.

Tabel 3 Kemampuan Penggunaan Ejaan Bahasa Indonesia

\begin{tabular}{|l|c|}
\hline \multicolumn{1}{|c|}{ Ejaan Bahasa Indonesia } & Jumlah Kesalahan \\
\hline Huruf Kapital & 50 \\
\hline Huruf Miring & 20 \\
\hline Tanda Titik & 45 \\
\hline Tanda Koma & 30 \\
\hline Kata Baku & 30 \\
\hline
\end{tabular}

\section{Kemampuan Menyusun Sistematika Artikel Ilmiah}

Kemampuan menyusun sistematika artikel ilmiah mahasiswa PGSD UN PGRI Kediri tergolong baik yakni 85\% dapat menyusun sistematika artikel ilmiah. Sisanya $15 \%$ masih perlu bimbingan dalam menyusun sistematika. Mahasiswa yang dapat menyusun sistematika artikel ilmiah terdapat 17 kelompok. Dalam pengerjakan mahasiswa tersebut, sudah memuat sembilan sistematika artikel ilmiah yakni judul artikel, nama penulis, abstrak dan kata kunci, pendahuluan, metode penelitian, hasil penelitian, pembahasan, kesimpulan dan saran, dan daftar pustaka. Pada pembahasan 
ini, peneliti masih mengabaikan isi dari sistematika artikel. Peneliti hanya menganalisis dari sistematika artikel yang secara kasatmata dapat dilihat. Sisa kelompok yakni 3 atau 15\% masih perlu bimbingan. Tiga kelompok tersebut tidak mencantumkan kata kunci, pembahasan dan saran. Kata kunci diabaikan karena tidak merupakan esensi dari sistematika artikel ilmiah. Selain itu, mahasiswa belum mengetahui bahwa kata kunci merupakan bagian penting dari artikel. Mengenai pembahasan yang tidak dicantumkan dalam pengerjaan artikel, dikarenakan mahasiswa sudah membuat hasil penelitian. Dalam hasil penelitian sudah memuat semua temuan-temuan mahasiswa dalam penelitian tanpa perlu diadakan pembahasan. Terakhir, bagian saran mahasiswa tidak mencantumkannya dikarenakan terletak di bagian akhir pengerjaan sebelum daftar pustaka. Mahasiswa yang kurang teliti, bisa dipastikan tidak mencantumkan saran.

Mahasiswa yang perlu bimbingan dalam penyusunan artikel ilmiah adalah mahasiswa yang tidak hadir dalam perkuliahan materi karya tulis ilmiah. Mahasiswamahasiswa tersebut, tidak mengejar ketertinggalan materi perkuliahan selama tidak masuk. Hasilnya, mahasiswa menyusun artikel ilmiah kurang sesuai dengan sistematika artikel ilmiah. Kejadian tersebut, perlu diberi perhatian kepada dosen pengampu Bahasa Indonesia atau dosen pembimbing seminar dan skripsi.

\section{Kemampuan Menulis Isi Artikel Ilmiah}

Tujuan penelitian yang kedua yakni menganalisis kemampuan menulis isi artikel ilmiah mahasiswa PGSD UN PGRI Kediri angkatan 2016. Analisis isi artikel ilmiah berdasarkan sistematika artikel ilmiah. Semua mahasiswa dapat menulis judul artikel dengan baik. Judul dikatakan baik jika judul yang dibuat dapat memberikan gambaran yang jelas tentang materi ruang lingkup masalah yang akan dibahas dan menarik perhatian pembaca (Sugihastuti dan Siti Saudah, 2016:311). Untuk mempermudah mahasiswa, semua judul diarahkan ke penelitian kualitatif. Tujuannya, dalam penelitian kualitatif, isi penelitian mengutamakan uraian kata-kata daripada hitungan angka.

Sistematika kedua yakni abstrak dan kata kunci. Mahasiswa yang dapat membuat abstrak dan kata kunci dengan katergori baik adalah sejumlah 15 kelompok atau $75 \%$. Sisanya, 5 kelompok atau $25 \%$ masih perlu bimbingan. Isi abstrak 
mengikuti aturan masing-masing institusi. Dalam pengerjaan abstrak, berisi latar belakang, tujuan, jenis penelitian, sumber data, data penelitian, teknik pengumpulan, teknik analisis, teknik keabsahan data, dan kesimpulan penelitian. Untuk kata kunci mengacu pada variabel yang terdapat dalam judul penelitian. Sebanyak 15 kelompok yang dikategorikan baik telah memenuhi isi abstrak dan kata kunci sesuai dengan aturan yang berlaku. Kelompok yang berjumlah 5, tidak bisa mengisi dengan baik atau perlu bimbingan. Penyebabnya sebanyak 3 kelompok tidak mencantumkan kata kunci, sedangkan dua kelompok yang lain salah dalam penulisan kata kunci. Sesuai dengan teori penulisan kata kunci merujuk pada variabel peneltiian.

Sistematika ketiga, yakni pendahuluan. Pengerjaan pendahuluan sebanyak 12 kelompok atau 60\% dikategorikan baik, sisanya 8 atau 40\% kelompok dikategorikan perlu bimbingan. Bagian pendahuluan menurut Sugihastuti dan Siti Saudah (2016:312) berisi latar belakang masalah, tujuan pembahasan, ruang lingkup/ pembatasan masalah, teori yang dipakai, sumber data, metode dan teknik yang digunakan dan sistematika penyajian. Isi pendahuluan tersebut untuk skripsi, sedangkan untuk artikel ilmiah lebih sederhana. Dalam artikel ilmiah, pendahuluan berisi latar belakang penelitian, ruang lingkup atau batasan penelitian dan tujuan penelitian. Latar belakang berpola dari hal-hal rinci (khusus) ditarik kesimpulan ke umum. Hal tersebut, sesuai dengan penelitian kualitatif. Pola penelitian kualitatif berisi dari masalah khusus atau studi kasus pada suatu tempat/ lokasi penelitian kemudian dijabarkan untuk dijadikan kesimpulan. Ruang lingkup berisi mengenai batasan penelitian, dapat berupa batasan variabel objek atau subjek. Tujuan penelitian berisi tujuan peneliti dalam melakukan penelitian. Sebanyak 12 kelompok yang dikategorikan baik karena dalam pengerjakan pendahuluan telah memuat ketiga hal yakni latar belakang, ruang lingkup, tujuan serta berpola khusus-umum. Berbeda dengan 8 kelompok yang dikategorikan perlu bimbingan. Letak pembimbingan terdapat pada 1) isi latar belakang kurang fokus atau masih bersifat umum, 2) tidak berpola khusus-umum, melainkan umum-umum, dan 3) tidak terdapat ruang lingkup atau batasan penelitian. Mahasiswa kurang fokus atau kasuistis dikarenakan mahasiswa kurang mendalami dan memahami fenomena. Mahasiswa mengerjakan tidak berpola khusus-umum tetapi umum-umum dikarenakan mahasiswa perlu banyak membaca karya ilmiah sehingga dapat menulis dengan baik. Mahasiswa tidak 
menyertakan ruang lingkup penelitian, alasannya lupa dan dikatakan bukan masalah penting dalam penelitian. Ketiga hal tersebut, perlu dijadikan perhatian oleh dosen pembimbing seminar maupun skripsi.

Sistematika keempat, yakni metode penelitian. Dalam pengerjaan metode penelitian, sebanyak 17 kelompok atau 85\% dikategorikan baik. Sisanya, sebanyak 3 kelompok atau 15\% dikategorikan perlu bimbingan. Metode penelitian, berisi jenis penelitian, sumber data dan data, jenis pengumpulan dan analisis data, dan jenis keabsahan data. Sebanyak 17 kelompok dapat memenuhi isi metode penelitian dengan baik. Sisanya, sebanyak 3 kelompok mengalami kendala pada 1) masih kebingungan membedakan sumber data dan data, 2) kurang variatif dalam menentukan jenis analisis data, dan 3) tidak mencantumkan jenis keabsahan data. Ketiga kendala tersebut, dikarenakan mahasiswa kurang bersemangat dalam mencari referensi penelitian. Akibatnya pengetahuan mengenai karya tulis ilmiah terutama penelitian kualitatif masih minim.

Sistematika kelima, yakni hasil penelitian. Pada bagian ini, berisi mengenai pemaparan hasil analisis penelitian tanpa disertai pembahasan. Ada adanya hasil penelitian disajikan tanpa adanya kutipan dari penelitian lain. Sebanyak 9 kelompok atau 45\% dikategorikan baik, sisanya 11 kelompok dikategorikan perlu bimbingan. Dikategorikan baik, dikarenakan dalam pengerjaan terdapat analsis suatu fenomena sesuai dengan jenis analisis yang telah dipaparkan pada metode penelitian. Kelompok yang perlu bimbingan, dikarenakan analisis yang dilakukan tidak sesuai dengan metode penelitian. Selain itu, pada bab pendahuluan mahasiswa yang tidak mencantumkan ruang lingkup penelitian maka akan kebingungan dalam memberi batasan dan analisis yang tepat. Hasilnya, penelitian tidak fokus dan meluas.

Sistematika keenam, yakni pembahasan. Pada bagian ini, merupakan kelanjutan dari sistematika hasil penelitian. Jika, pada bagian hasil penelitian berupa pemaparan hasil penelitian, maka bagian pembahasan merupakan bentuk uraian dari hasil penelitian. Uraian dapat berupa deskripsi yang menggambarkan sumber data dalam menghasilkan data. Dengan demikian, penelitia bisa mengungkap alasan terjadinya sesuatu secara lebih mendalam dan fokus. Hal tersebut, menjadi perbedaan penelitian kualitatif dan kuantitatif. Penelitian kualitatif difokuskan pada uraian katakata sehingga dapat diketahui secara mendalam fenomena yang terjadi. Berbeda 
dengan penelitian kuantitatif yang berupa angka-angka untuk mengukur suatu perlakuan atau kejadian tanpa bisa mengungkap alasan dibalik suatu kejadian. Sebanyak 3 kelompok atau 15\% dikategorikan baik karena dapat mengungkap secara mendalam hasil penelitian. Sisanya, 17 kelompom atau $85 \%$ dikategorikan perlu bimbingan dengan alasan sebagai berikut. 1) Mahasiswa tidak mencantumkan bagian pembahasan alasannya dalam penelitian bagian yang terpenting adalah hasil penelitian tanpa adanya pembahasan dari hasil penelitian. Pendapat lain, menyebutkan jika sudah ada hasil penelitian, tidak perlu diberi pembahasan. 2) Mahasiswa tidak melakukan penelitian dengan mendalam, dikarenakan data penelitian berupa teks tanpa disertai adanya observasi atau wawancara mengenai teks tersebut. 3) mahasiswa kurang pandai dalam menyusun kata, akibatnya isi dalam pembahasan sama dengan hasil penelitian. Ketiga alasan tersebut, dapat diatasi jika mahasiswa sering membaca karya tulis ilmiah dan sering menulis karya ilmiah.

Sistematika ketujuh, yakni kesimpulan dan saran. Semua kelompok memuat dan mengisi bagian tersebut dengan baik. Dalam kesimpulan, mahasiswa menyimpulkan hasil penelitian sesuai dengan tujuan penelitian. Untuk saran, berisi mengenai tips yang perlu dilakukan pembaca. Jika pembaca selaku peneliti, diberi saran agar melakukan penelitian yang baik. Artinya, kendala atau permasalahan yang terjadi oleh mahasiswa (peneliti) tidak terulang kepada pembaca selaku peneliti selanjutnya. Jika pembaca selaku penikmat karya tulis ilmiah, diberi saran sesuai hasil penelitian agar mendapatkan pengetahuan yang lebih baik.

Sistematika kedelapan, yakni daftar pustaka. Sugihastuti dan Siti Saudah (2016:315) menyatakan bahwa daftar pustaka merupakan daftar buku, majalah, artikel di dalam majalah atau surat kabar, atau artikel di dalam kumpulan karangan yang digunakan sebagi acuan dalam penelitian. Sebanyak 19 kelompok atau 95\% dikategorikan baik. Alasannya, dapat menulis daftar pustaka sesuai dengan aturan dan semua hasil kutipan di dalam karya ilmiah dimasukkan ke daftar pustaka. Sisanya, 1 kelompok atau 5\% dikategorikan perlu bimbingan. Alasannya, masih kebingungan dalam menulis daftar pustaka seperti penulisan nama penulis buku perlu dibalik, penulis buku yang lebih dari dua ditulis semua oleh mahasiswa dan judul buku tidak ditulis miring. Selain itu, tidak semua kutipan disertakan dalam daftar pustaka. 


\section{Kemampuan Penggunaan Ejaan Bahasa Indonesia}

Kemampuan terakhir yang menjadi tujuan penelitian yakni kemampuan mahasiswa dalam menggunakan ejaan bahasa Indonesia pada penulisan karya ilmiah. Berdasarkan hasil penelitian, terdapat beberapa kesalahan penggunaan ejaan bahasa Indonesia. Berikut pembahasan penggunaan ejaan bahasa Indonesia dalam penulisan karya ilmiah mahasiswa.

Pertama, penggunaan huruf kapital ditemukan sebanyak 50 huruf yang ditulis tidak sesuai ejaan bahasa Indonesia. Ketidaksesuaian tersebut, dikategorikan dalam dua kesalahan. Penggunaan huruf kapital yang pertama yakni penulisan nama mata pelajaran. Penulisan nama mata pelajaran termasuk dalam nama diri sehingga penulisannya menggunakan huruf kapital pada huruf pertama suatu kata. Kenyatannya, sebanyak 38 kata yang memuat nama mata pelajaran ditulis menggunakan huruf kecil. Penggunaan kapital yang salah kedua yakni penulisan nama bulan dan peristiwa sejarah. Sebanyak 12 kata yang memuat nama bulan peristiwa sejarah ditulis menggunakan huruf kecil. Seharusnya, penulisan nama bulan dan peristiwa sejarah ditulis menggunakan huruf kapital pada huruf pertama suatu kata. Kesalahan pengunaan huruf kapital pada nama mata pelajaran, nama bulan dan peristiwa sejarah disebabkan karena mahasiswa menganggap nama mata pelajaran bukanlah nama penting. Hasilnya, kata-kata tersebut ditulis menggunakan huruf kecil. Mahasiswa beranggapan bahwa penulisan huruf kapital hanya untuk nama orang, agama dan daerah. Mahasiswa seharusnya sering melihat buku pedoman ejaan bahasa Indonesia dalam proses penulisan karya tulis ilmiah.

Kedua, penggunaan huruf miring ditemukan sebanyak 20 kata tidak ditulis miring. Dalam ejaan bahasa Indonesia, huruf miring digunakan untuk judul buku, penegasan kata dan istilah asing. Sebanyak 20 kata tidak ditulis miring terdapat pada penulisan istilah asing. Mahasiswa kurang memperhatikan bahwa penggunaan huruf miring untuk istilah asing yang belum ditemukan padanan kata dalam bahasa Indonesia.

Ketiga, penggunaan tanda titik ditemukan sebanyak 45 salah penulisan. Kesalahan penggunaan tanda titik dilakukan mahasiswa pada subjudul. Seharusnya penulisan subjudul ditulis tanpa menggunakan tanda titik diakhir subjudul. Kenyatannya, mahasiswa memberi tanda titik pada akhir subjudul. Mahasiswa kurang 
memahami pada penggunaan tanda titik pada kalimat, bukan pada judul atau subjudul.

Keempat, penggunaan tanda koma ditemukan sebanyak 30 salah penulisan. Kesalahan penggunaan tanda koma pada kata hubung. Aturan penggunaan tanda koma yakni setelah kata hubung pada awal kalimat dan sebelum kata hubung pada tengah kalimat. Mahasiswa yang menggunakan kata hubung tidak menggunakan tanda koma. Mahasiswa beranggapan penulisan tanda koma pada anak kalimat yang mendahului induk kalimat, memisahkan kata seru dengan kalimat, memisahkan nama dengan gelar, dan kata yang ditulis berangkai dan berurutan.

Kelima, penggunaan kata baku ditemukan sebanyak 30 kata. Kata baku adalah kata yang telah ditentukan dalam pedoman umum ejaan bahasa Indonesia berdasarkan kriteria tertentu. Sebanyak 30 kata yang tidak termasuk dalam kata baku bahasa Indonesia. Mahasiswa dalam penulisan karya ilmiah kurang memperhatikan kata baku dan tidak baku, terutama kata-kata asing yang telah ditemukan padanan kata dalam bahasa Indonesia. Kata-kata yang dituliskan mahasiswa sebenarnya telah ada padanan kata dalam bahasa Indonesia, tetapi mahasiswa kurang cermat. Kosa kata yang lazim digunakan dalam karya ilmiah sudah ditulis oleh mahasiswa sesuai kebakuan kata. Dengan demikian, mahasiswa seharusnya sering membuka Kamus Besar Bahasa Indonesia atau Pedomaan Umum Ejaan Bahasa Indonesia untuk menambah wawasan mengenai suatu kata yang telah dibakukan. Hal tersebut, sesuai dengan karakter bahasa yakni bersifat dinamis. Bahasa mengalami perubahan dan terjadi serapan bahasa asing untuk mengisi kekurangan kosa kata suatu bahasa.

\section{PENUTUP}

\section{Kesimpulan}

Berdasarkan hasil penelitian, kemampuan mahasiswa dalam menulis karya ilmiah pada mata kuliah Bahasa Indonesia dijabarkan dalam tiga bentuk. Pertama, kemampuan menulis sistematika artikel ilmiah. Sebanyak 17 kelompok atau 85\% dikategorikan baik atau dapat menulis sistematika artikel ilmiah. Sisanya, 3 kelompok atau $15 \%$ dikategorikan perlu bimbingan. Kedua, kemampuan mahasiswa dalam menulis isi artikel ilmiah. Isi pada penulisan judul, nama penulis, abstrak, metode penelitian, dan daftar pustaka mahasiswa dikategorikan baik karena lebih dari $75 \%$ 
sudah bisa menulis. Sisanya, pada penulisan pendahuluan, hasil penelitian, pembahasan, kesimpulan dan saran, mahasiswa dikategorikan perlu bimbingan dikarenakan hanya 25\% yang dapat menulis dengan baik. Ketiga, kemampuan penggunaan ejaan bahasa Indonesia. Ditemukan beberapa kesalahan, yang perlu diperhatikan yakni kesalahan huruf kapital, huruf miring, tanda titik, tanda koma, dan kata baku. Kesalahan tersebut, dikarenakan mahasiswa kurang membaca karya ilmiah, sehingga pengetahuan penggunaan ejaan bahasa Indonesia masih relatif kurang.

\section{Saran}

Semua sistematika karya tulis mempunyai peran penting terhadap hasil penulisan karya ilmiah. Apabila ada satu bagian terlewatkan atau dikerjakan dengan asal, maka akan berpengaruh pada bagian lain. Dengan demikian, peneliti perlu memperhatikan semua bagian dalam penulisan karya ilmiah dengan penuh ketelitian dan tanggungjawab.

\section{DAFTAR RUJUKAN}

Arikonto, Suharsimi. 2010. Prosedur Penelitian Suatu Pendekatan Praktik. Jakarta: Rineka Cipta.

Brotowijoyo, Mukayat D. 2002. Penulisan Karangan Ilmiah. Jakarta: Akademika Pressindo.

Ismawati, Esti. 2012. Bahasa Indonesia untuk Penulisan Karya Ilmiah. Yogyakart: Penerbit Ombak.

Moleong, Lexy. 2005. Meotodologi Penelitian Kualitatif. Bandung: Remaja Rosdakarya.

Pemerintah Indonesia. 2012. Undang-Undang Nomor 12 Tahun 2012 tentang Pendidikan Tinggi. Lembaran RI Tahun 2012 Nomor 158. Jakarta: Sekretariat Negara.

Sugihastuti dan Siti Saudah. 2016. Buku Ajar Bahasa Indonesia Akademik. Yogyakarta: Pustaka Pelajar.

Suyitno, Imam. 2011. Karya Tulis Ilmiah (KTI), Panduan, Teori, Perlatihan, dan Contoh. Bandung: Refika Aditama. 